\title{
Hashino Blast Furnace Relics Honored by ASM Historical Landmark Award*
}

\author{
By Eikichi YOSHITAKE**
}

Dr. Donald J. Blickwede, President of the American Society for Metals (ASM), presented the honorable Historical Landmark Award to Saijiro Hamakawa, Mayor of Kamaishi City, at Marine Hotel on April 3, 1984.

The bronze plaque award was brought with the President all the way from Metals Park, Ohio, in the United States. Hashino blast furnace relics in Kamaishi was cited for its role in the modernization of the Japanese iron- and steel-making industry, which took its first step there in December, 1857.

The award was instituted in 1971 by ASM with the objective of celebrating those people, places, ideas and facilities that rendered great contributions to the development of metalworking technology mainly in North America. All but five (three in Canada and two in Mexico, respectively) of the ASM Historical Landmarks are in the United States, and this is the first time a site outside North Americathe relics of the Hashino blast furnace-has been honored as an ASM Historical Landmark.

At the end of January the Iron and Steel Institute of Japan (ISIJ) received a kindly offer from President D. J. Blickwede to present the Historical Landmark Award to the birthplace of the modern Japanese steel industry. The Institute examined prudently a variety of places and officially decided to recommend Hashino blast furnace relics as the best site proposed for the award on February 22, 1984. In late March ISIJ, thereupon, was informed that the board of trustees of ASM unanimously approved

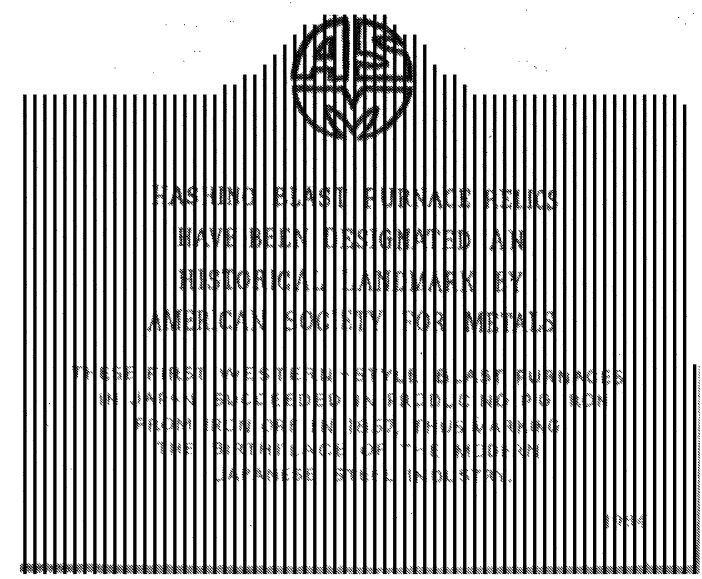

Photo. 1. Bronze historical landmark award. the proposal.

After attending the 69th Annual General Meeting of the Institute held on April 1, Dr. D. J. Blickwede and Mr. A. R. Putnam, ASM Senior Managing Director, and their wives left the next day for Kamaishi by the Tohoku Shinkansen Line. During their travels to Kitakami Station, the whole crew enjoyed the passing snowy landscape of the Sendai plain. They were greeted at the station by the Japanese parties concerned and from there drove to Rakuzanso, the guest house kindly provided by Kamaishi Iron and Steel Works of Nippon Steel Corporation.

That night at the welcome dinner hosted by Kamaishi Iron and Steel Works the Blickwedes and the Putnams had a most hearty reception from more than 20 of the steel and municipal interests led by General Superintendent Asai of Kamaishi Iron and Steel Works, two Deputy General Superintendents, Mayor Hamakawa and Chairman Hasegawa of the municipal assembly.

On the following day, April 3, the guests went to the ceremonial site in the wake of a visit through the iron and steel plants. In the award ceremony, far better attended than the preceding night, an ISIJ official explained briefly the background of the landmark designation and subsequently the president and the senior managing director presented the Historical Landmark Award accompanied with the following words from the Senior Managing Director:

"In presenting this award, it is our privilege to represent the officers and board of trustees as well as the over 53000 members worldwide of the American Society for Metals. The award was preserving American metallurgical heritage, while at the same time providing a means to increase the awareness of pioneering milestones of metalworking technology."

"Today, the scope of the award has been expanded to include man's greatest metalworking achievements from around the world. The initial Historical Landmark Award was presented in 1972, marking the site of the first electric arc steelmaking furnace in the Western Hemisphere at the Crucible Speciality Metals Division of Colt Industries. In the past eight years, 37 additional historical landmarks have been named, incluading the site we honor today. Next month, Dr. Blickwede and I will represent ASM at only the second Historical Landmark presentation outside the Western Hemisphere, at the Ironbridge in Englandthe world's first iron bridge. But it is the business of

\footnotetext{
* Originally published in Tetsu-to-Hagané, 70 (1984), 981, in Japanese. English version received May 15, 1984. (C) 1984 ISIJ

** The Iron and Steel Institute of Japan, Otemachi, Chiyoda-ku, Tokyo 100.
} 
today to honor this site, the first ASM Historical Landmark outside North America-the Relics of the Hashino Blast Furnace. Well, then, I will have Dr. Blickwede offer some background information on the Site's history."

In the greeting following Putnam's introduction, Dr. Blickwede, quoting the words of the first ISIJ President, said, "In 1891, Kageyoshi Noro, one of the greatest Japanese metallurgical engineers, wrote, ' Steel is the mother of industry and the basis for national security. Without steel, there can be no industry... For it is recognized that the steel industry determines the destiny of a nation.' If this is true, then I think we can say that today's industrial Japan was born here, at the site we honor today."

" Until the end of the Edo Period, iron- and steelmaking technology in Japan was based on the classic Tatara Method of smelting and iron forging. This method was sufficient for the production of swords, farm implements, tools, and utensils in modest numbers. But there was no way the method could keep up with the needs of shipbuilding and machinery repair as Japan began to modernize.'

" In Europe, the smelting of iron ore by charcoal blast furnaces had been developed by the mid-14th century. Japan was four or five centuries behind when the first successful Japanese blast furnace was built here in 1857-But it was a first, critical step toward industrialization. The first successful tapping of the blast furnace came on December 1, 1857."

"The Kamaishi mines nearby were ideally suited for making pig iron with a blast furnace. There was a rich supply of high quality iron ore easily obtained by open pit mining, and the district had thick forests, guaranteeing an adequate supply of charcoal. Water for energy, clay for bricks, and granite for the furnace shell was also abundant in the area. There was ample demand for Kamaishi-produced iron for the manufacture of farm implements, household utensils, private minting and other uses. There were a total of 10 Kamaishi blast furnaces, with a combined annual production capacity of some $3000 \mathrm{t}$ in 1868.

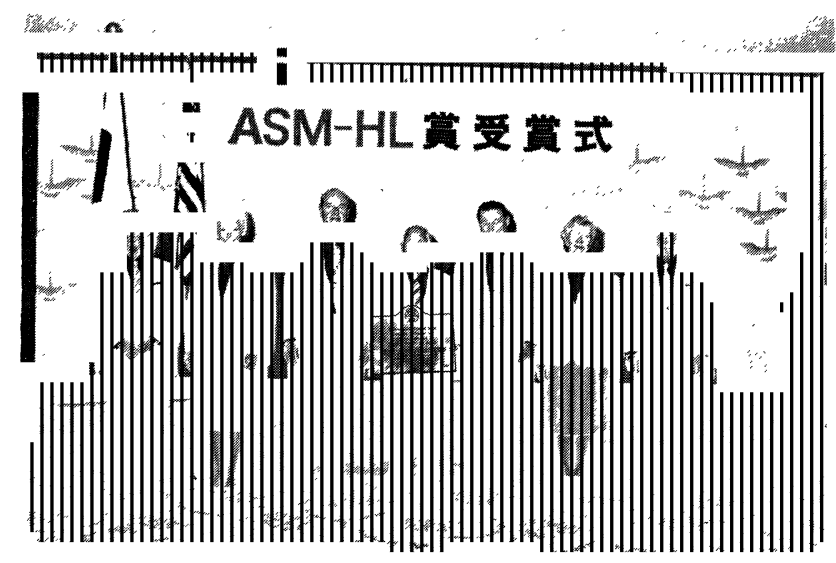

Photo. 2. Award ceremony of ASM-HL award at Kamaishi. (From right to left, General Superintendent of Kamaishi Iron and Steel Works, NSC, Mr. \& Mrs. Putnum, the Mayor of Kamaishi City, Dr. \& Mrs. Blickwede, and Author)
And the blast furnace operations gradually grew, forming a basis for the growth of a modern industry on a nationwide scale."

Once again Mr. Putnam said to close their remarks, "Quite clearly, this site well meets the requirements established for qualification as an Historical Landmark of the American Society for Metals."

He added, "Mayor, would you come forward, please. We would like to present you with this inscribed scroll bearing the Historical Landmark citation. The scroll, like the plaque, reads:

\section{HASHINO BLAST FURNACE RELICS HAVE BEEN DESIGNATED AN HISTORICAL LANDMARK BY AMERICAN SOGIETY FOR METALS}

\author{
THESE FIRST WESTERN-STYLE BLAST FURNACES \\ IN JAPAN SUGCEEDED IN PRODUGING PIG IRON \\ FROM IRON ORE IN 1857, THUS MARKING \\ THE BIRTHPLACE OF THE MODERN \\ JAPANESE STEEL INDUSTRY.
}

To those words, may we add the congratulations of the officers, members, and staffs of the American Society for Metals."

Then, the recipient, Mayor Hamakawa, expressed his sincere gratitude. We enjoyed a friendly chat with the guests at the celebration later, where they were presented with memorials by the mayor and also were treated to "Tora-Mai", a traditional and noted dancing performance of Kamaishi.

The time came when we proceeded to the relics of the Hashino blast furnace. Driving about an hour up a mountain-path with deep snow on either side, we arrived at "Aonoki." The snow lay more than one meter deep on the ground around there. But the road leading to the relics had been put in good condition with the snow cleared away three meters wide and with red carpets running.

The guests and their party were met by local junior and senior high school girls lined the road and carried small flags of Japan and the United States, who belong to groups for preservation of historic remains. When

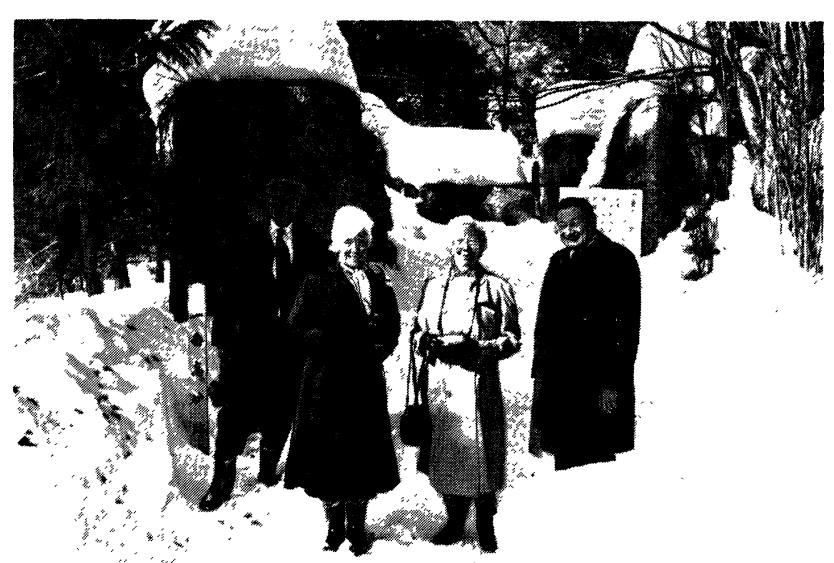

Photo. 3. At Hashino Blast Furnace Relics, Kamaishi. (Dr. \& Mrs. Blickwede and Mr. \& Mrs. Putnum) 
the Blickwedes and the Putnams advanced there with faces beaming with delight, one of girls gave a speech of welcome in polished English. Dr. Blickwede immediately thanked her for her greeting. It was a heartwarming scene.

On the site we found outer granitic walls of the blast furnace to be well preserved. Mr. Itazawa, a member of the Kamaishi Gultural Properties Protection Committee, gave a full detail of the preserving status.

Once again those present were very conscious of how difficult the blast furnace operation must have been in Hashino among the mountains in old days; besides, everything about these relics is reminiscent of the pioneers' delights in their first successful tapping of the blast furnace. Surely, the operations here paved the way for today's prosperity of Japanese steel industry as Dr. Blickwede told in his greeting.

In leaving the site the guests offered their thanks to the attendants, Deputy Mayor Mori and Deputy General Superintendent Oya of the Kamaishi Iron and Steel Works, and were given a good sendoff. And their short trip to Kamaishi, which would not easily be forgotten, was over. 